\title{
Magnetic Properties of Submarine Basalts from Site 443 of DSDP Leg 58, the Shikoku Basin
}

\author{
Shinji TAKAHASHI \\ Department of Earth Sciences, \\ Faculty of Science, Kobe University, Kobe, Japan \\ (Received March 2, 1982; Revised October 15, 1983)
}

\begin{abstract}
Thermomagnetic properties, lattice constants and optical properties of $\mathrm{Fe}-\mathrm{Ti}$ oxide minerals contained in 31 submarine basalt samples from the Shikoku basin (Site 443 of DSDP Leg 58) were studied. It seems to be clarified by this work that the magnetic properties are not dependent on depth from sub-bottom at the drilling site but on their lithological facies. As the result of the thermomagnetic analysis of the magnetic minerals separated magnetically from these samples, they were classified in four types (i.e. 1. reversible 2. semi-irreversible 3. irreversible 4. high Curie temperature). Specimens in the irreversible type seems to be reconstituted by a certain heat treatment. This fact shows us the necessity of reconsideration of the mechanism of a thermo-chemical change in low temperature-oxidized (non-stoichiometric) minerals.
\end{abstract}

\section{Introduction}

The magnetic properties of $\mathrm{Fe}-\mathrm{Ti}$ oxide minerals have been precisely studied over several decades and many studies of magnetic properties of these minerals in submarine basalts have been reported.

OzIMA and LARSON (1967) reported that titanomagnetites ( $\beta$-phase) were transformed into ilmenite-hematite phase ( $\alpha$-phase) by heating. O'REILLY (1968) reported that low temperature oxidation of titanomagnetites increased their Curie temperature. Using synthesized magnetites, OzIma and SaKamoтo (1971) reported that low temperature oxidation of titanomagnetites decreased their lattice constants in addition to the increasing of the Curie temperatures. OzIMA and OzIMA (1971) reported the chemical changes such that one phase of titanomagnetite was transformed into two phases (less-titaniferous magnetite phase and Ti-rich $\mathrm{Fe}-\mathrm{Ti}$ oxide phase), with which the irreversible changes of $J_{s}-T$ curve in natural submarine basalts could be plausibly interpreted. MARSHALL and Cox (1972) concluded that low temperature oxidation accompanied by weathering had some effect on the changes in the lattice constant and Curie temperature of the samples. The chemical composition of oceanic tholeiites are different from the continental ones (MIYASHIRO, 1976). The $X$-value $\left[X \mathrm{Fe}_{2} \mathrm{TiO}_{4}(1-X) \mathrm{Fe}_{3} \mathrm{O}_{4}\right]$ of titanomagnetites in the submarine basalts are reported to be about 0.6 (e.g. JoHNSON and HALL, 1978; Hamano et al., 1979). 
FURUTA et al. (1980) studied magnetic properties of submarine basalts from Site 443 of Leg 58. Using 27 samples from the drill core, an optical and electron microprobe analyses of opaque minerals was made and these results were compared with the shipboard magnetic data, i.e. magnetic polarities, $J n, M D F$ etc. In their results, they reported the existence of 2 types, 1 ) thermally reversible and 2) thermally irreversible, which were classified by the shape of their $J_{S-T}$ curves; They also reported various features of titanomagnetites, of ilmenites and of the other opaque minerals by microscopic observation, and an ulvospinel content of $X=0.6$ from electron microprobe analysis. Since their results were obtained from only about half of the drilling core samples of basalts from Site 443 of DSDP Leg 58, it is necessary to examine the rest of the samples in order to discuss the characteristics in detail.

KLEIN et al. (1980) reported that five units were identified in the basalt sequence in Hole 443:

Unit 1 (457.0-457.1 m sub-bottom)

Unit 2 (457.1-500.2 m sub-bottom) plagioclase olivine phyric basalt

Unit 3 (500.2-538.5 m sub-bottom) aphyric basalt (piloow lavas)

Unit 4 (538.5-552.8 m sub-bottom) plagioclase olivine phyric basalt

Unit 5 (552.8-576.5 m sub-bottom) plagioclase (sparsely) phyric basalt

Unit 6 (576.5-581.5 m sub-bottom) olivine plagioclase phyric basalt

According to KLEIN et al. (1980), pillow basalts occur at Site 443, while the basalts overlying and intercalated with the pillows are massive basalts. A detailed discription of the stratigraphy of these basalts was reported by DiCK et al. (1980). Some massive basalts were identified as sills or sheets intruding into sediments.

The purpose of this study is as follows:

(1) To supplement the study of FURUTA et al. (1980).

(2) To obtain the differences of magnetic properties between submarine samples and continental samples or synthesized ones.

(3) Consideration of the mechanism of the mode of thermo-chemical changes related to the "low temperature oxidation" and the "high temperature oxidation".

It is important for us to study magnetic properties of submarine basalts in company with their mineralogical and petrological properties.

\section{Thermomagnetic Measurements of Virgin Samples}

Thermal changes of saturation magnetization, $J s$, were measured on 31 virgin samples from Site 443 . The magnetic minerals, separated from the basalts with a magnet, were heated at the approximate rate of $10^{\circ} \mathrm{C}$ a minute in a magnetic field of about 3,000 Oe. After attaining $620^{\circ} \mathrm{C}$, they were cooled to room temperature at the same rate in the same field. The heating and cooling were done in a vacuum of 


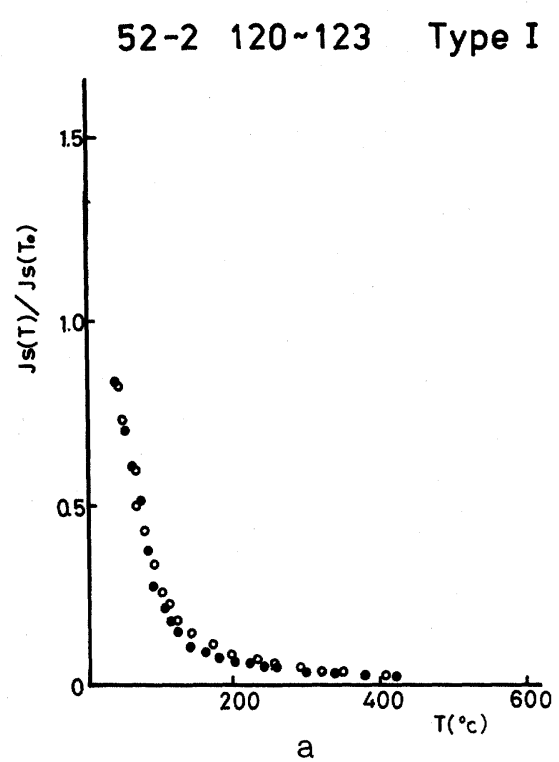

54-7 138 140 Type II

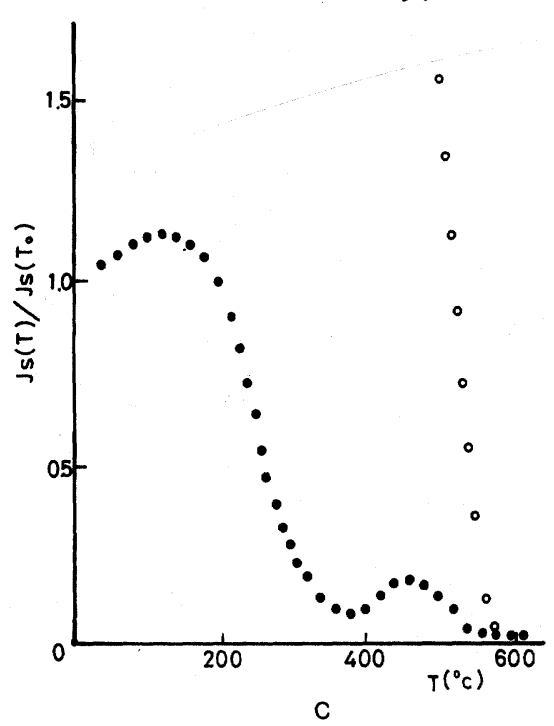

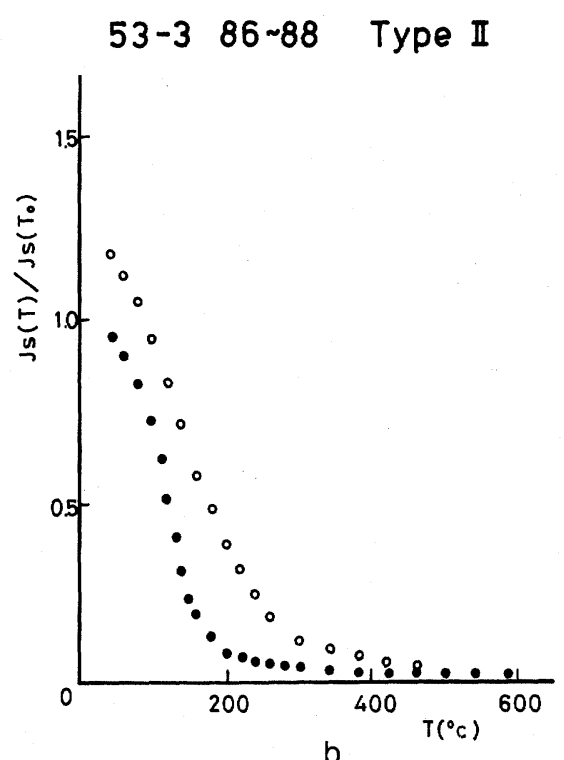

b

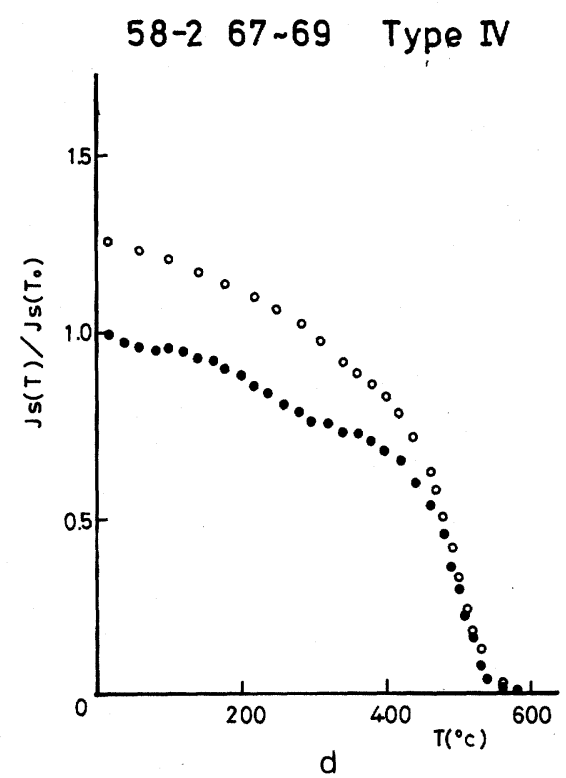

Fig. 1. $J_{s-T}$ curves of four typical types of virgin specimens. Closed circles show the heating process; open circles show the cooling process. (a) $J_{S}-T$ curve of reversible type in low temperature type. (b) $J_{S}-T$ curve of semi-irreversible type in low temperature type. (c) $J s-T$ curve of irreversible type in low temperature type. (d) $J s-T$ curve of irreversible type in high temperature type. 
$10^{-3}$ torr. All Curie temperature values were determined using the graphic method of GROMME et al. (1969).

As a result, four types of thermomagnetic curves were recognized: thermally reversible (Fig. 1-a), thermally semi-irreversible (Fig. 1-b), and thermally irreversible (Fig. 1-c) in low Curie temperature type, and thermally irreversible in high Curie temperature (Fig. 1-d). These are temporarily called Type I, II, III and IV, respectively. Type I, II and III are common in many submarine basalts (e.g. OzIMA and Ozima, 1971; Hamano et al., 1979), but Type IV is not.

In the reversible type, the Curie temperature $\left(T c_{1}\right)$ is easily determined, as shown in Fig. 1-a. In semi-irreversible and irreversible curves, more than two Curie temperatures, $\left(T c_{1}, T c_{2}, \ldots, T c_{h}\right)$ are recognized. $T c_{h}$, the Curie temperature after heating process up to $620^{\circ} \mathrm{C}$, is nearly the same or slightly higher than the highest $T c_{1}$ seen in the heating process. The multiple Curie temperatures seem to be due rather to the stepwise transformation of titanomagnetite into less-titaniferous magnetite and a certain Ti-rich Fe-Ti oxide mineral at approximate temperatures (e.g. OzIMA et al., 1968 ; OzIMA and LARSON, 1970) than to the coexistance of multiple magnetic phases in the virgin specimens.

There is only a single example $(58-2,67 \sim 69)$ of high Curie temperature type (Type IV) in this study; the Curie temperature of it is about $550^{\circ} \mathrm{C}$, nearly equal to the Curie temperature of pure magnetite.

The intensity ratio of saturation magnetizations at room temperature before and after heating at $620^{\circ} \mathrm{C}, J h_{0} / J_{0}$, were calculated from the results of the thermomagnetic measurements and are listed in Table 1 with the Curie temperature. Their ratios are in the range from 0.95 to 4.50 .

\section{Thermomagnetic Measurements after Heat Treatment}

The specimens after the thermomagnetic measurements were enclosed in quartz glass at vaccum of $10^{-3}$ torr and were heated by san electric furnace. Higher heat treatments than before were done successively, using the same specimen, to examine the thermal contribution to the chemical change of the mixing.

Thermal changes of saturation magnetization, $J s$, of the heated specimens were measured under the same thermomagnetic conditions as the virgin specimens.

In the case of $61-4,106 \sim 108$ (Figs. $2-a, b$ and c), the thermomagnetic curves of specimens heated directly from the virgin state to $100^{\circ} \mathrm{C}$ for 48 hours and to $150^{\circ} \mathrm{C}$ for 100 hours $(2-b, 2-c)$ are almost same as the curve of the virgin specimen (2-a). This result suggests that the titanomagnetites have not yet been destroyed at $150^{\circ} \mathrm{C}$.

In the case of 59-1, $12 \sim 14$ (Figs. 3-a, b and c), the specimens of the curves were heated after the first run at $680^{\circ} \mathrm{C}$ for 3 hours and $900^{\circ} \mathrm{C}$ for 5 hours. These curves obviously differ from the curve of the virgin specimen. Comparing Fig. 3-a with 3-b and 3-c, it is clear that $T c_{1}$ of 3-b and 3-c are lower than $T c_{h}$ of 3-a; therefore the chemical changes that occurred might be as follows: The titanomagnetites unmixed into a less-titaniferous magnetite phase and a non-magnetic phase as the result of the 

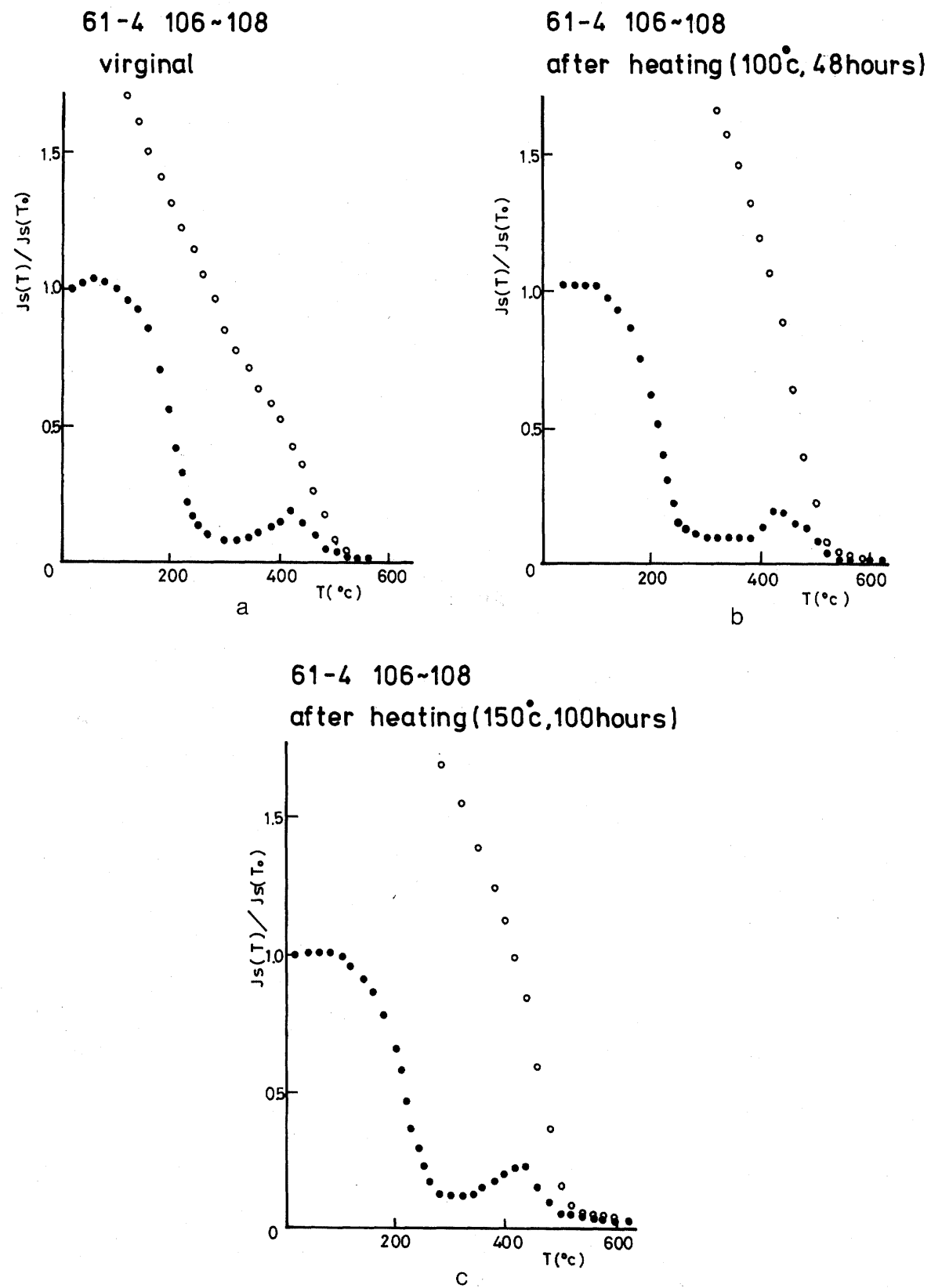

Fig. 2. $J_{S-T}$ curves of a specimen heated at high temperatures. Closed circles show the heating process ; open circles show the cooling process. Figures 2-(b) and 2-(c) are after successive heat treatment of the virgin specimen in Fig. 2-(a). 

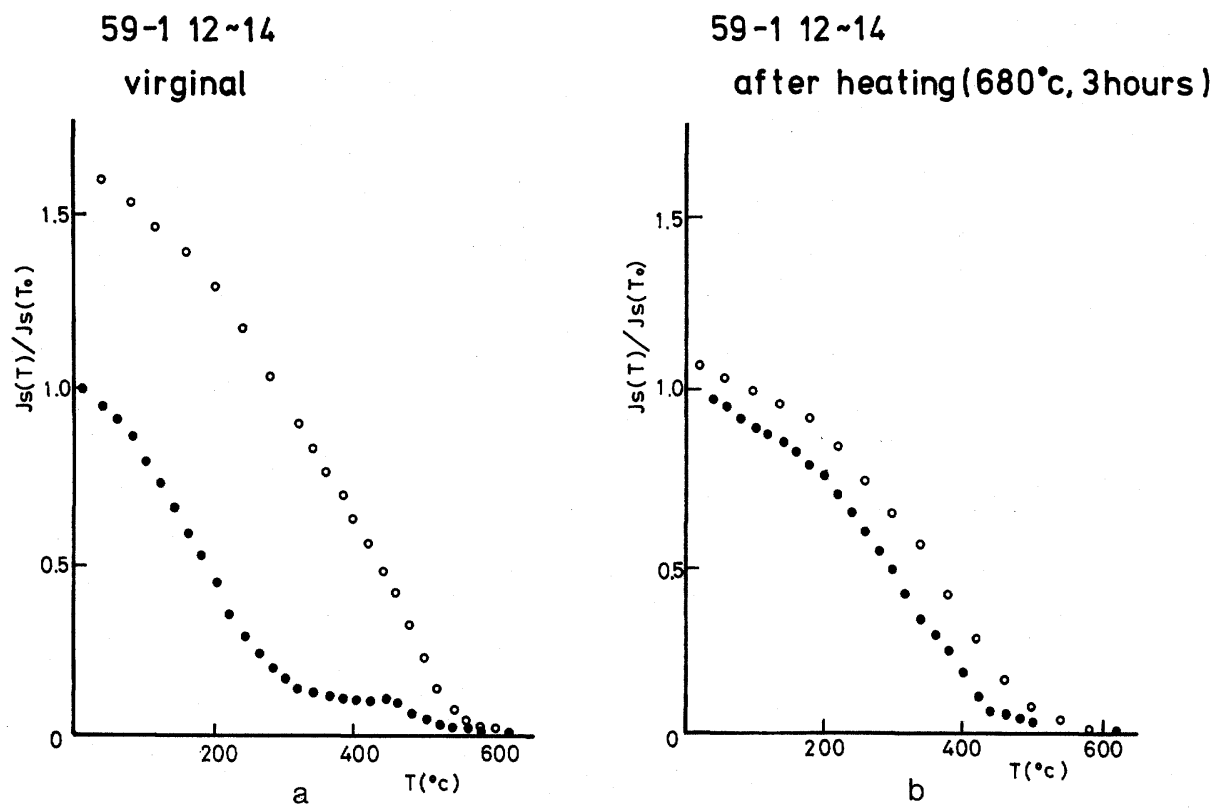

\section{9-1 12 -14 \\ after heating $\left(900^{\circ} \mathrm{C}\right.$, 5hours)}

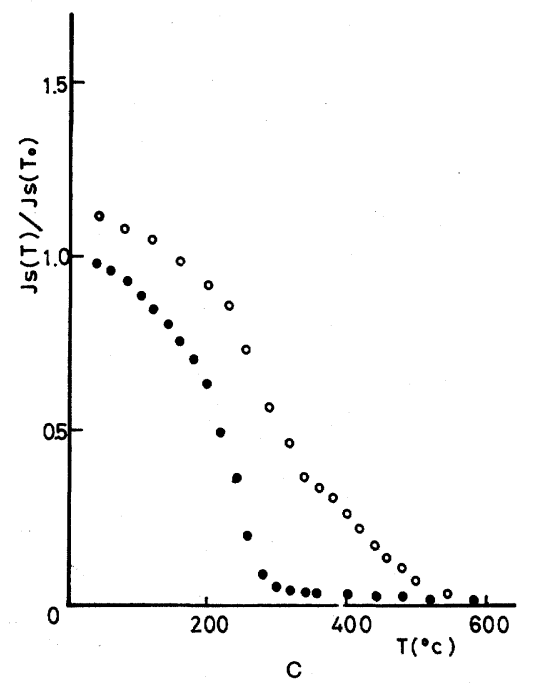

Fig. 3. $J s-T$ curves of a specimen heated at high temperatures. Closed circles show the heating process; open circles show the cooling process. Figure 3-(b) is for the heated specimen after the measurement shown in Fig. 3-(a). The measurement for the heated specimen in Fig. 3-(c) was taken after that one shown in Fig. 3-(b). 

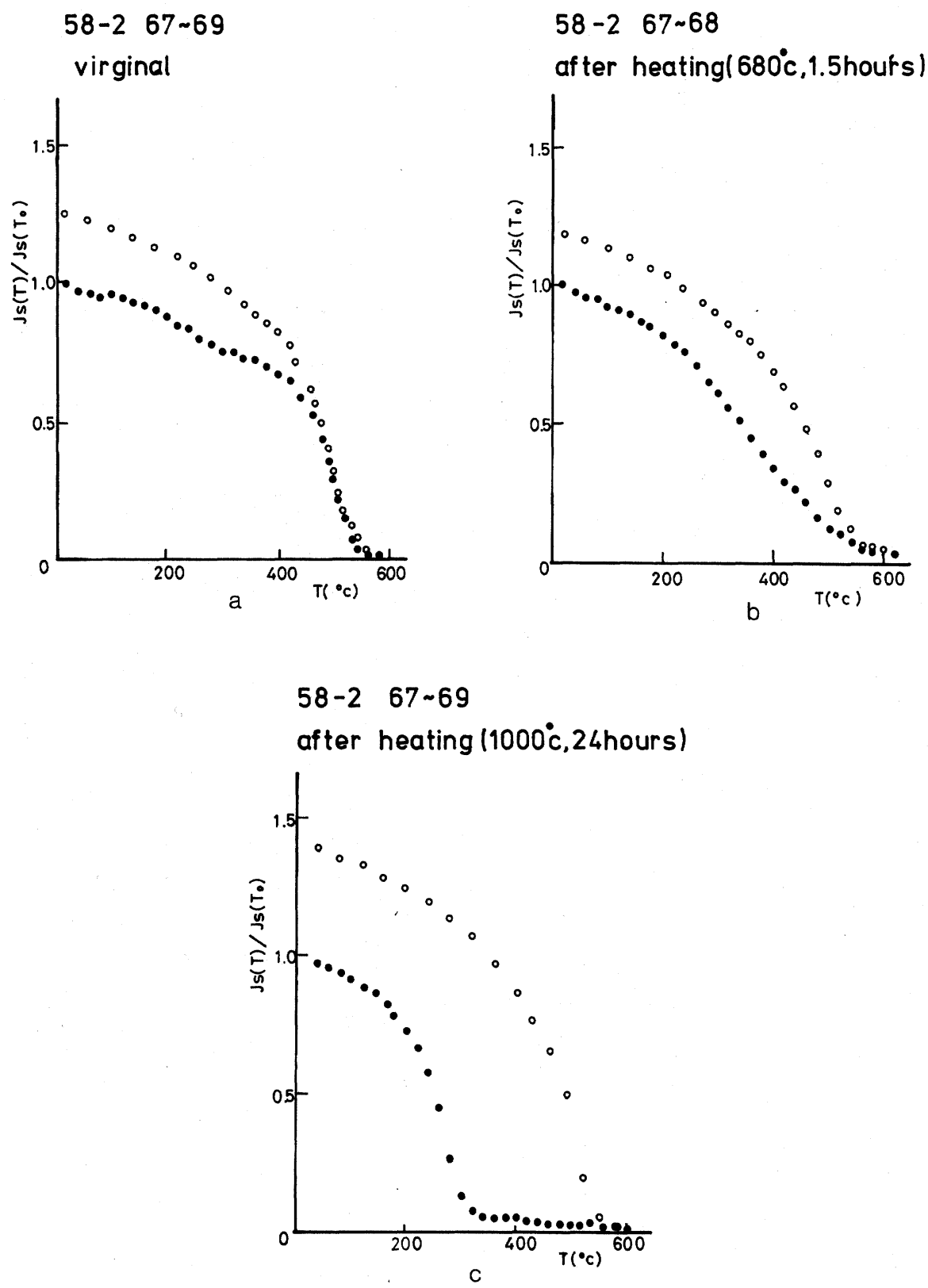

Fig. 4. $J s-T$ curves of a heated specimen of Type IV. Closed circles show the heating process; open circles show the cooling process. The curves in Figs. 4-(b) and (c) are after successive heat treatments of the same specimens. 
heating to $620^{\circ} \mathrm{C}$ in the first run and, subsequently, a new titanomagnetite was synthesized from these two phases in the higher heat treatment processes mentioned above.

Figure 4 shows thermomagnetic curves of the Type IV specimen $(58-2,67 \sim 69)$ heated at various temperatures. It is seen in this figure that the Curie temperatures of the heated specimens are lower than the Curie temperature of the virgin specimen. From the result, we can conclude the following: If the chemical composition of the magnetic grains in specimen $58-2,67 \sim 69$ is the same as the others, the high Curie temperature of the thermomagnetic curve of the virgin specimen may be interpreted by assuming that these grains are a comparison of two phases, one being a low titanium magnetite and the other being a particular Ti-rich $\mathrm{Fe}-\mathrm{Ti}$ oxide which is nonmagnetic above room temperature; these two phases were then synthesized into a new titaniferous magnetite trough heat treatment, the Curie temperature of which is lower than that of the virgin specimen. And, progressively, higher heat treatments caused more and more Ti to enter the titanomagnetite lattice.

It is reported that the Curie temperature of the cooling process appear at a lower point than that of the heating process in some $J s-T$ curves because of re-mixing of the unmixed phases which is accompanied with reduction, when the oxygen fugacities during heating is very low (MARShall, 1978; STAINER, 1982). Heat treatment in higher temperature may have caused a further reduction of the magnetic grains, as well as the lower oxygen fugacities during heating.

From the result of the thermomagnetic measurements of the heated specimen, it is recognized that the magnetic minerals of Type III and Type IV specimens do not seem to be mixed back perfectly into the chemically stable magnetic minerals as contained in Type I specimens.

\section{Microscopy of Opaque Minerals}

Opaque minerals were examined in polished sections with the reflected light microscope. Titanomagnetite was distinguished from ilmenite by its color and optical anisotropy, and from iron-sulfides by its color. As for iron-sulfides, pyrrhotite was distinguished from pyrite by its optical anisotropy. The majority of titanomagnetite and titanomaghemite grains were optical uniform as seen in Plate 1. In general, as to the shapes of titanomagnetites, the majority of them belong to skeletal (Plate 2) type or herring-bone type (Plate 3). But a few of the platy type (Plate 4), which are euhedral, were also observed in each section. Some titanomagnetites have well developed cracks (Plate 4), which were also reported by HALL et al. (1976), JoHnson and HALL (1978), KoBAYASHi et al. (1979), and GuruTA et al. (1980). Plate 5 shows titanomagnetite containing ilmenite evolution lamellae along (111) planes. Plate 6 shows herring-bone type ilmenite which is judged from optical anistropy and $\mathrm{Ti} / \mathrm{Fe}$ ratio analyzed by the electron microprobe. Since this is not the crystal habit of ilmenite, it could be titanomagnetite that have been replaced by ilmenite. Many grains of pyrrhotite and pyrite were observed in each polished section. And a few grains of goethite and chromian spinel were also observed in some polished sections. 


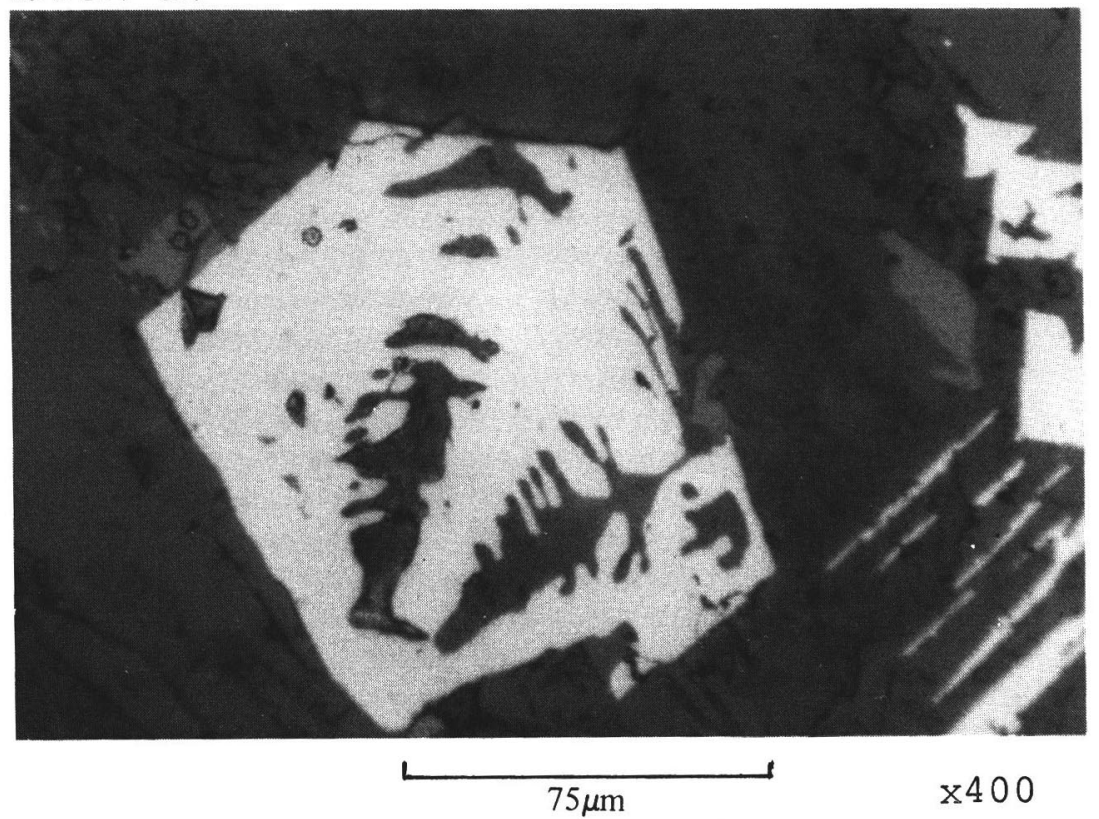

Plate 1. The titanomagnetite which is optically uniform.

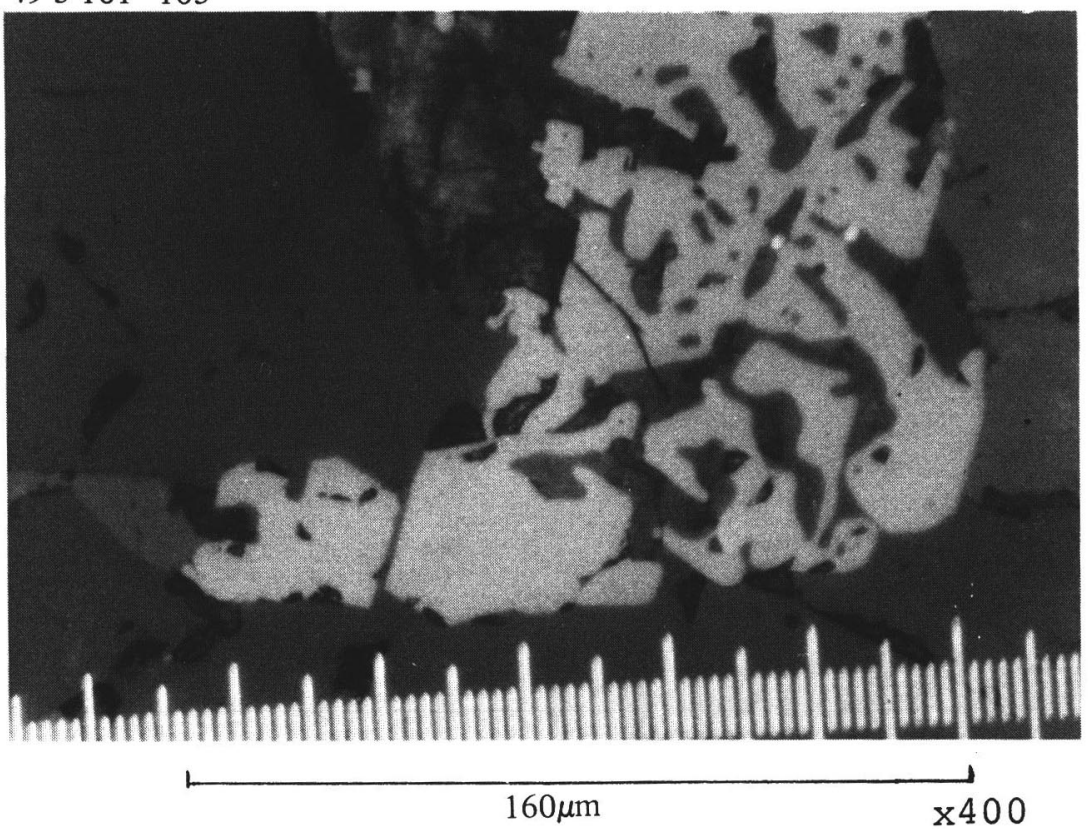

Plate 2. The skeletal type titanomagnetite. 
$52-2120 \sim 123$

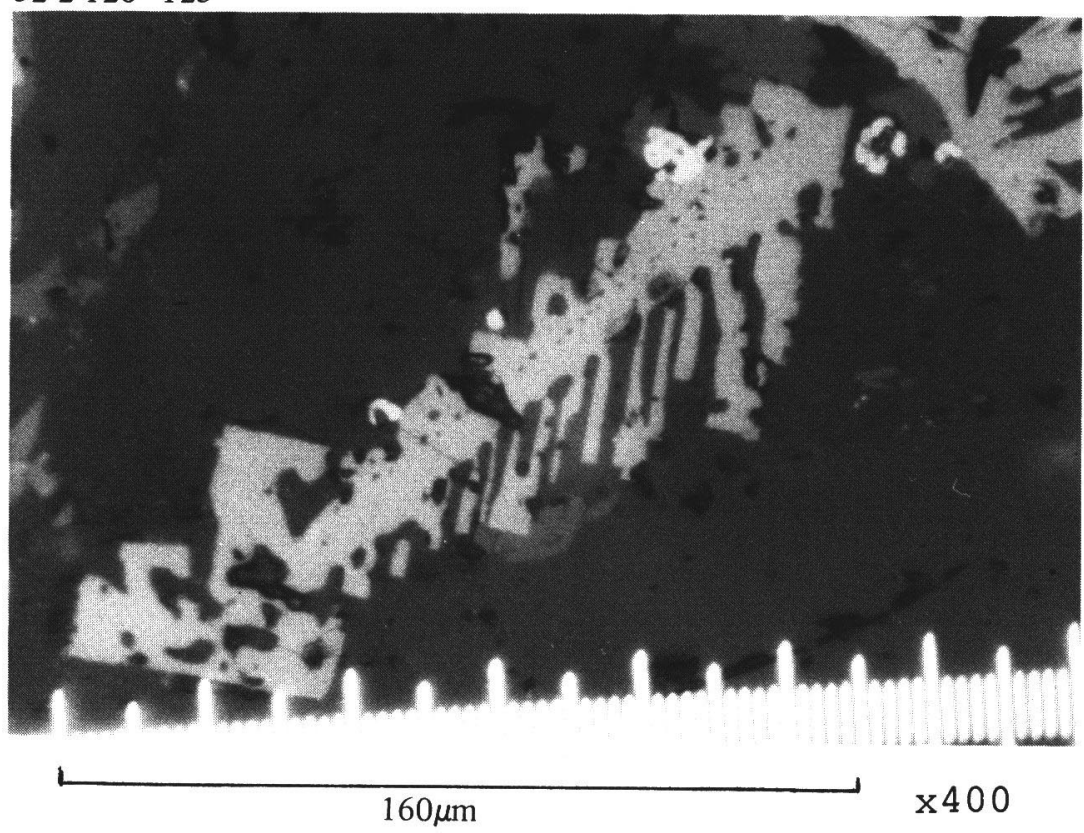

Plate 3. The herring-bone type titanomagnetite.

$59-4142 \sim 144$

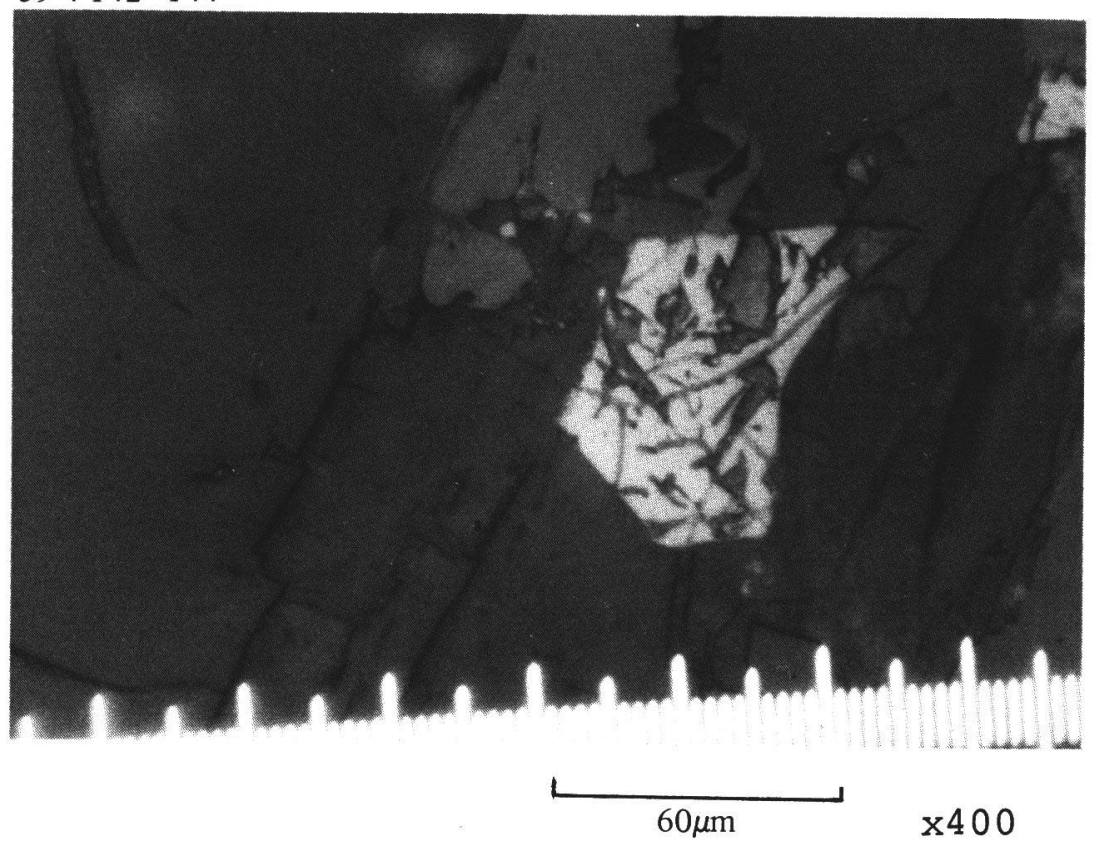

Plate 4. The platy type titanomagnetite, which have well developed cracks. 


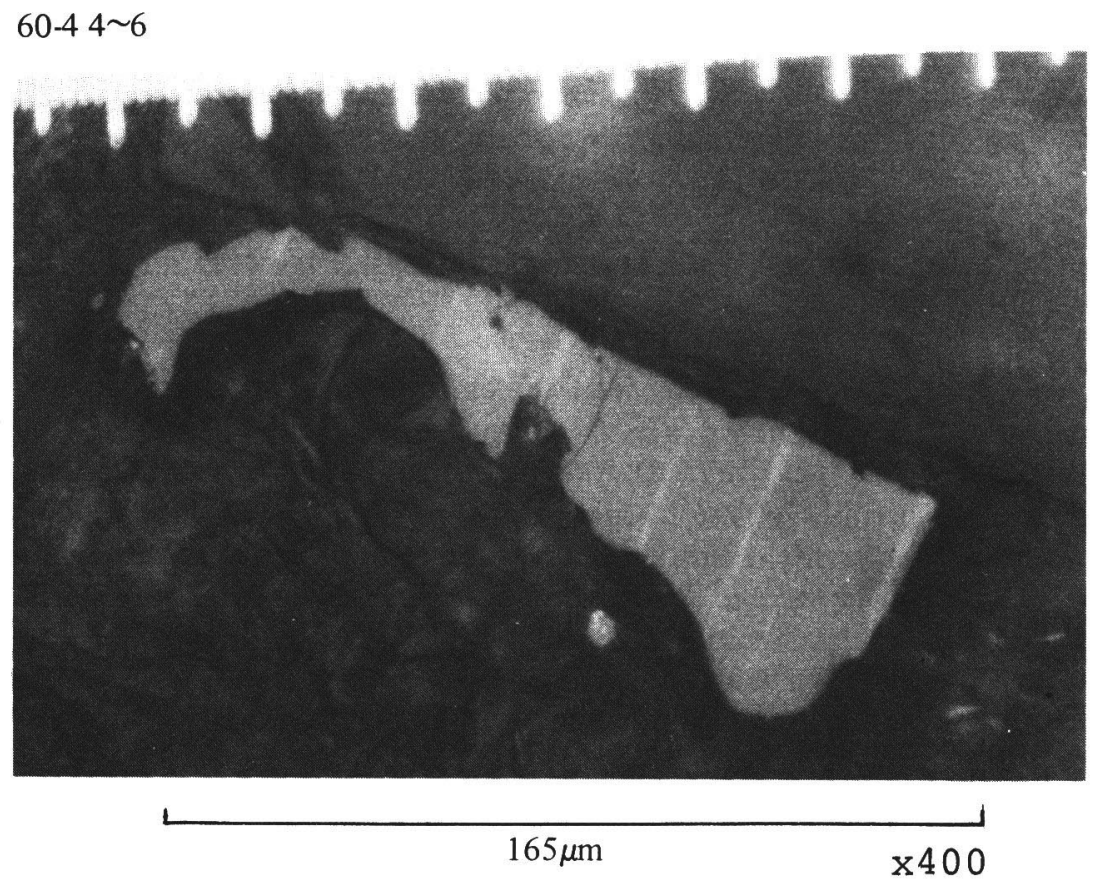

Plate 5. The titanomagnetite containing ilmenite exsolution lamellae along (111) planes.

\section{$63-5137 \sim 139$}

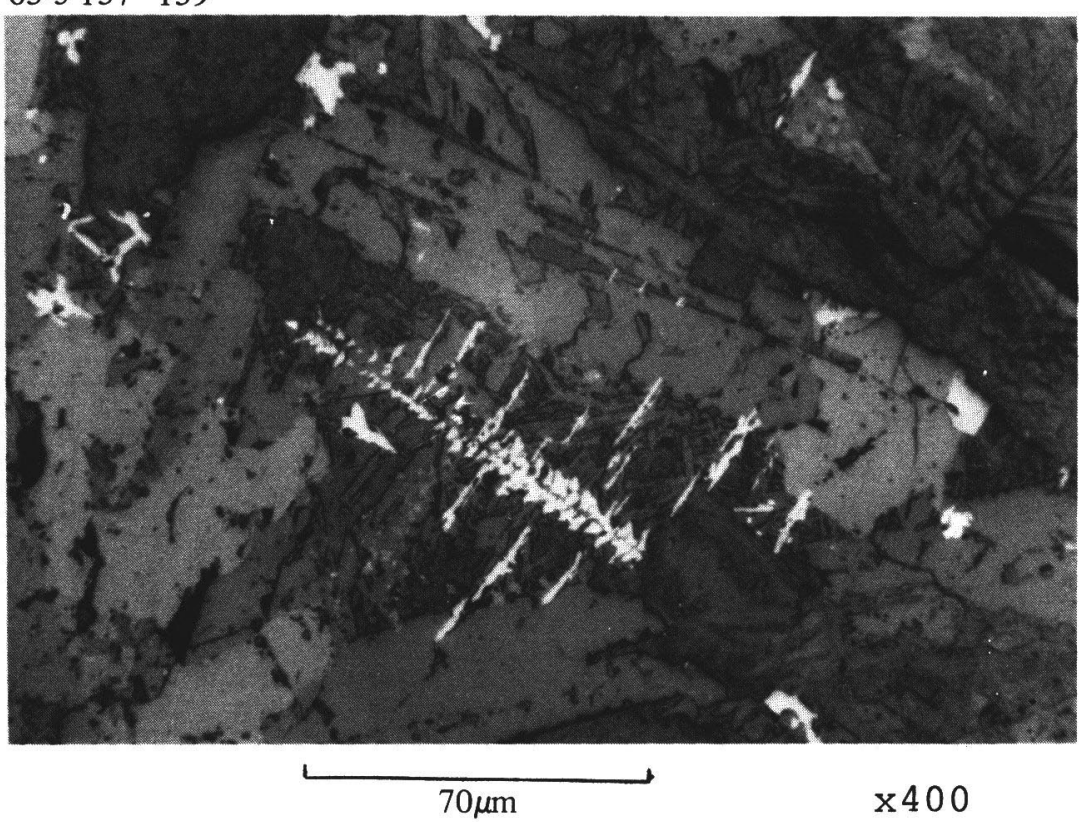

Plate 6. The herring-bone type grain which have optical anisotropy. 


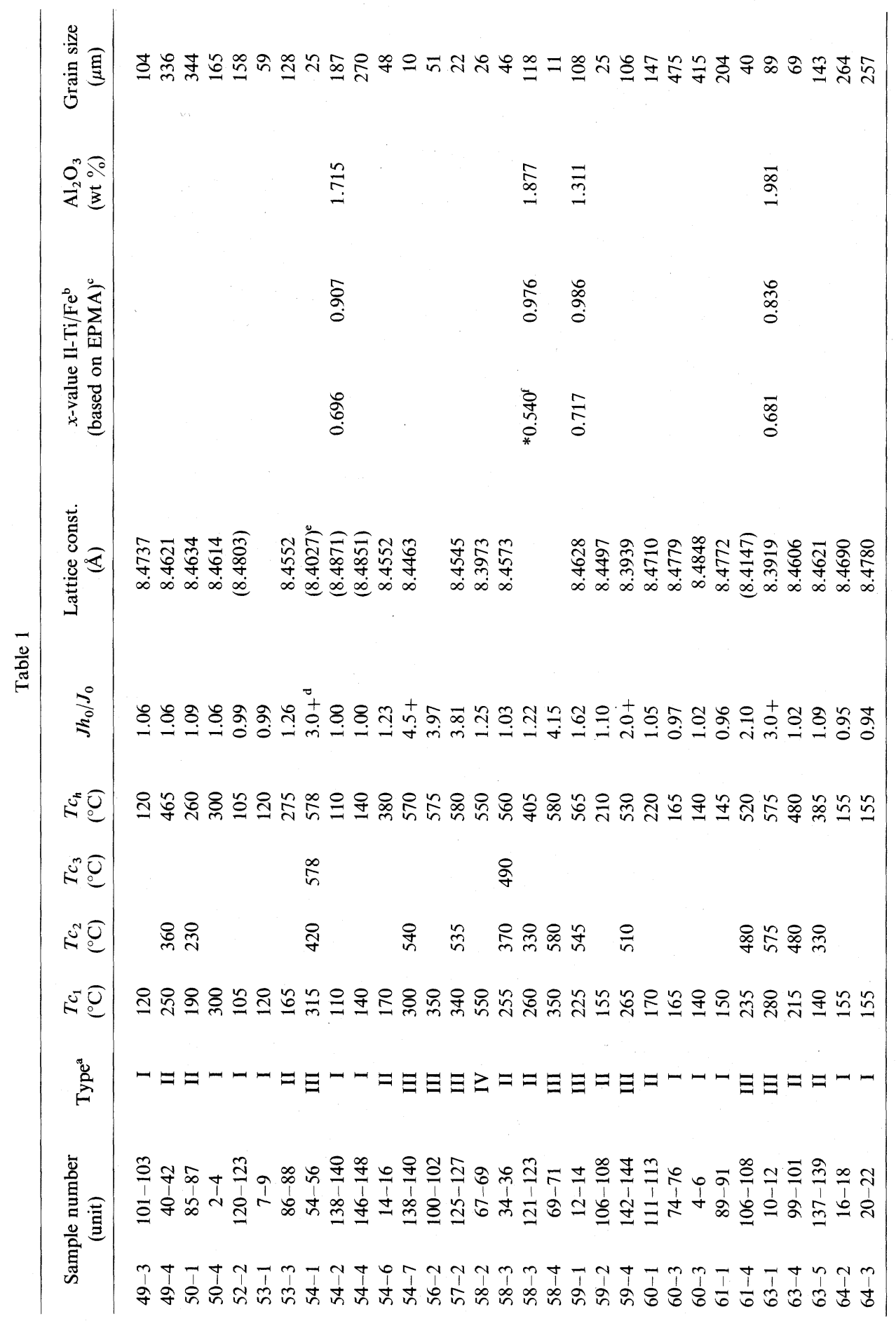


A determination of the grain size of titanomagnetite was applied to about ten of the largest grains in order to obtain the correction between grain size and thermomagnetic properties, as the thermomagnetic measurements are influenced by larger grains of titanomagnetite contained in the specimen. This grain size of titanomagnetite is listed in Table 1.

5. Relation between Lattice Constant and Curie Temperature of Titanomagnetite

Lattice constant of titanomagnetite was measured by use of Geiger Flex, RDAIIIA X-ray deflaction analyzer. Silicon was used as a standard. The peaks of $\mathrm{Cu} \mathrm{K} \alpha_{1}$ ray, deflected from (440), (511), (422), (400), (222) and (311), were measured. The lattice constants of their peaks were determined from the Miller index, respectively, and they were averaged. The results are listed in Table 1. The lattice constant was not determined for some samples because only a small amount of titanomagnetite was contained in them. Figure 5 shows distribution of lattice constant of titanomagnetite or titanomaghemite is related to its titanium content and to the degree of low temperature oxidation (e.g. OzIMA and LARSON, 1970; OzIMA and SAKAMOTo, 1971; MARSHALl and Cox, 1972).

Figure 6 shows the mutual relation between lattice constant and Curie temperature within the $\mathrm{FeO}-\mathrm{TiO}_{2}-\mathrm{Fe}_{2} \mathrm{O}_{3}$ ternary diagram. As seen in Fig. 6, the chemical compositions of the titanomagnetite of each type are different from each other. The $X$-value of Type I and Type II are concentrated between 0.6 to 0.7 . Four samples of Type III is too small a number to emphasize the $X=0.7$ value, however, the $X$-value of Type III seems greater than 0.7 and its chemical composition is rich in $\mathrm{Fe}_{2} \mathrm{O}_{3}$. The $X$-value of Type IV is nearly equal to 0.2 and this value implies that the titanomagnetite phase is poor in titanium.

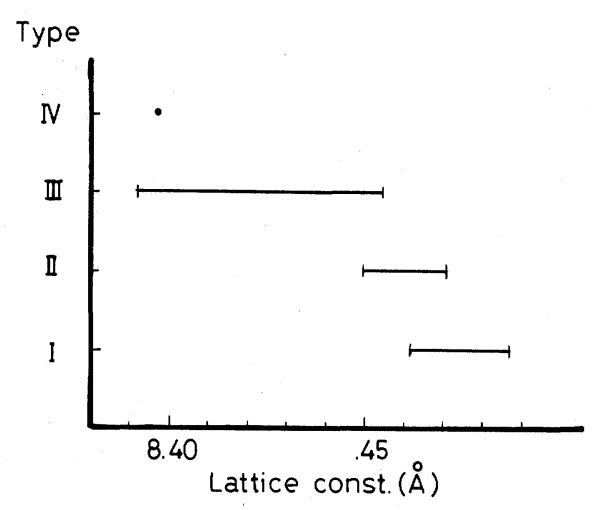

Fig. 5. The distributions of lattice constants in four types. 


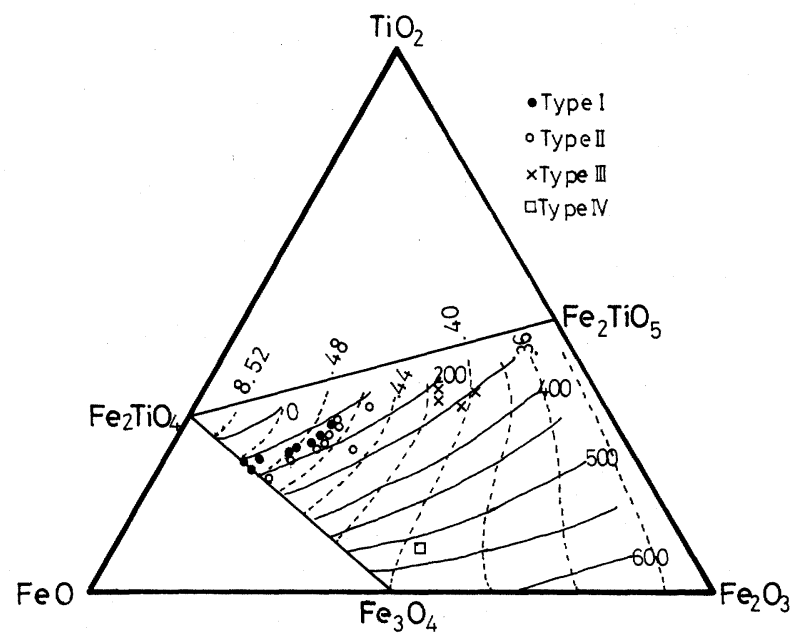

Fig. 6. The chemical compositions of titanomagnetites on the $\mathrm{FeO}-\mathrm{TiO}_{2}-\mathrm{Fe}_{2} \mathrm{O}_{3}$ ternary diagram, which are determined by their Tc contours (solid lines) and lattice constant contours (dashed lines) are those of NisHITANI (1979).

\section{Electron-Microprobe Analysis of Opaque Minerals}

Specimens were analyzed for $\mathrm{Al}, \mathrm{Ti}, \mathrm{Fe}$ and $\mathrm{Si}$. Content of $\mathrm{SiO}_{2}$ was monitored as a check against contamination, under the assumption that $\mathrm{Si}$ is extremely limited or absent in the $\mathrm{Fe}-\mathrm{Ti}$ oxide minerals.

If the grain size was larger than $10 \mu \mathrm{m}$, the $\mathrm{Ti} / \mathrm{Fe}$ ratio in titanomagnetite and ilmenite was determined by use of a JAX-5 electron-probe microanalyser in the University of Tokyo. The following selected minerals were used as standard materials: $\mathrm{Si}$ : synthetic quartz; $\mathrm{Al}$ : synthetic corundam; $\mathrm{Ti}$ : synthetic rutile; $\mathrm{Fe}$ : natural hematite (Sennin Mine, Iwate, Japan). The correction of NAKAMURA and KusHIRo (1970) was used for this analyses. Ulvospinel contents were calculated by first converting weight percentages into cations, normalized to three cations (i.e., under an assumption of stoichiometry). The cations of Ti and Fe were directly used to determine the $\mathrm{Ti} / \mathrm{Fe}$ ratio and hence the ulvospinel content $(\mathrm{X})$ for each grain. Since, unfortunately, most of the grains in the specimens have well developed cracks and scratches, only four specimens, which were suitable for microprobe and which

Fig. 7. $\mathrm{Al}_{2} \mathrm{O}_{3}$ weight percentage versus $\mathrm{Ti} / \mathrm{Fe}$ ratios in titanomagnetites. Closed circles are skeletal titanomagnetites; open circles are herring-bone titanomagnetites; crosses are platy titanomagnetites. The skeletal and the herring-bone are subhedral titanomagnetites as seen in Plate 2 and Plate 3. The platy type are euhedral titanomagnetites as seen in Plate 4. Squares indicate those which can not grouped into the above three type titanomagnetite. They are not euhedral and their shapes are not similar to the skeletal or the herring-bone titanomagnetites but are shapes such as nuts or beans. 

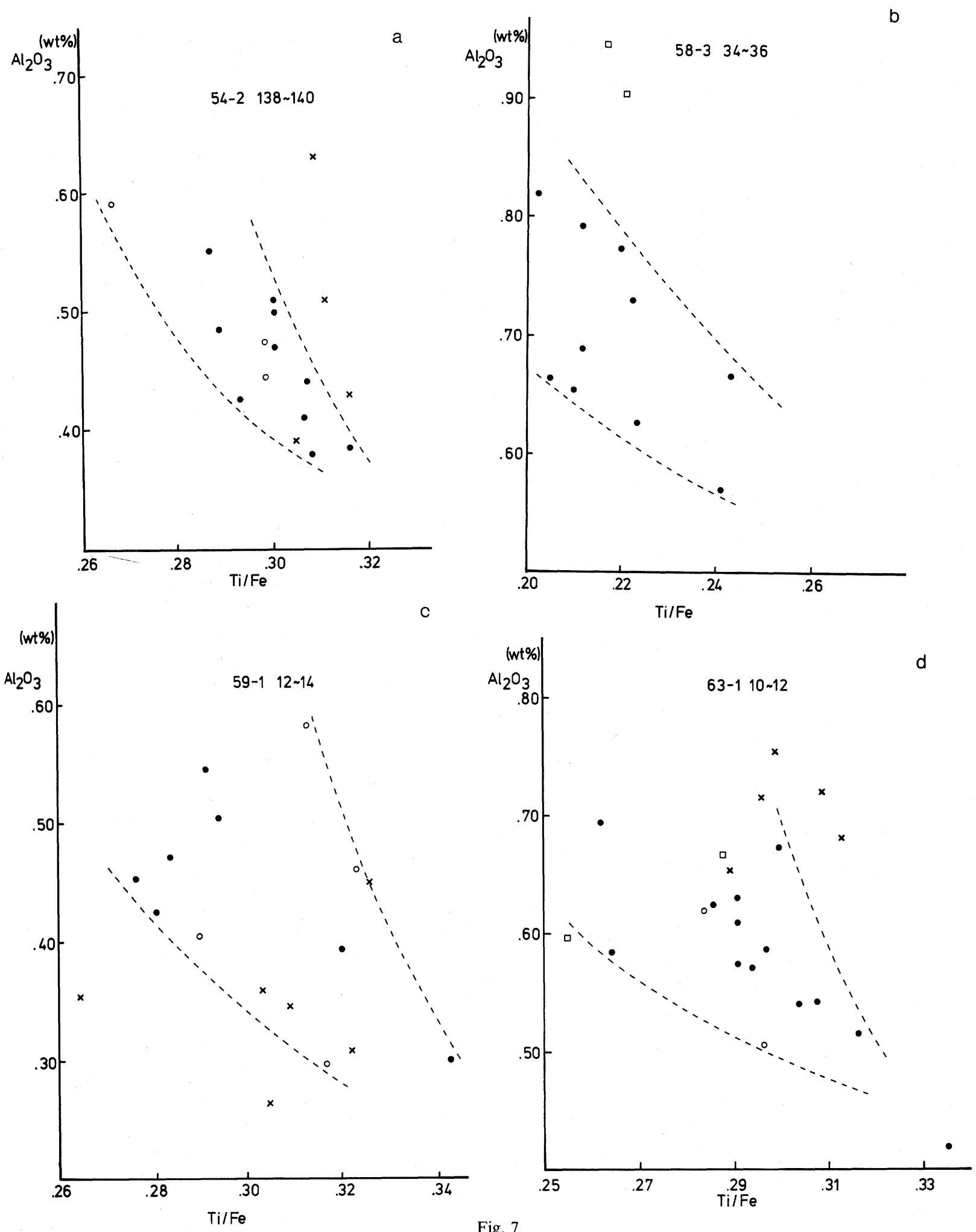

Fig. 7 
represented each type (except for Type IV), were selected for analysis. The chemical composition was determined by this method in more than 20 grains in each specimen and the results were averaged. The molecular ratio of Ti to Fe of ilmenite and $X$-value of titanomagnetite based on electron-microprobe analysis are shown in Table 1.

The $\mathrm{Al}_{2} \mathrm{O}_{3}$ content ranges from 1.3 to 2.0 (weight percentage) as seen in Table 1 . The existance of $\mathrm{Al}_{2} \mathrm{O}_{3}$ would slightly modify the $X$-value of the titanomagnetite if it is in a solid solution of magnetite-ulvospinel (Gromme et al., 1979; Furuta et al., 1980).

The correlation between the molecular ratio of $\mathrm{Ti}$ to $\mathrm{Fe}, \mathrm{Ti} / \mathrm{Fe}$, and weight percentage of $\mathrm{Al}_{2} \mathrm{O}_{3}$ is shown in Fig. 7. As seen in Fig. 7, the weight percentage of $\mathrm{Al}_{2} \mathrm{O}_{3}$ seems to increase when the molecular ratio of Ti to Fe decrease expect for the case of grains of the platy type, although the scatter is relatively large. This may be a petrologic (differentiation) trend.

\section{Discussion}

Magnetic properties, drilling depth and lithology had already been determined on board and they were reported in the Initial Report of DSDP (KLEIN et al., 1980). The grain sizes of the titanomagnetites, $T c_{1}, T c_{h}$ and $J h_{0} / J_{0}$ have been measured in this study. As seen in Fig. 8, it is clear that there is no obvious correlation between the magnetic properties and drilling depth, but there seems, however, to be a correlation between the magnetic properties and lithology. The grain sizes of titanomagnetites in aphyric basalts or pillow basalts are generally smaller than those in phyric basalts and the values of $T c_{1}, T c_{h}$ and $J h_{0} / J_{0}$ in aphyric basalts or pillow basalts are generally larger than those in phiric basalts (e.g. JOHNSON and HALL, 1978; KOBAYASHI et al., 1979; DAY et al., 1979; STAINER, 1982). Figures 9-a and b show that $T c_{1}$ and $J h_{0} / J_{0}$ depend on the grain sizes of titanomagnetites.

The major magnetic minerals in the samples of this study are titanomagnetites and their oxidized products, titanomaghemites. The iron-sulfides were observed in the polished sections under the reflected light microscope. Their quantities are not greater than those of titanomagnetites, but still considerable. They do not influence the $J s$ - $T$ curves because their saturation magnetization is much weaker than that of the titanomagnetites. In the case of Type I, the $J_{S}$ - $T$ curves are reversible (Fig. 1-a) and it means that the magnetic minerals are chemically stable in the thermomagnetic measurements. On the other hand, in case of Type II, Type III and Type IV, the $J s-T$ curves are semi-irreversible or irreversible (Figs. 1-b, c and d) and this means that they are chemically meta-stable or unstable in thermomagnetic measurements.

Ilmenite lamellae were not found in the polished section of Type IV (58-2, $67 \sim 69$ ) under the reflected light microscope. If its chemical composition is not much different from that of titanomagnetites which are contained in ordinary submarine basalts ( $X=0.60 .7$; e.g. HAMANo et al., 1979), it is reasonable to consider that the ilmenite-hematite phases are not contained in the form of lamellae which are chemically stable, but in the form of "immature" (FURUTA, 1981) ilmenite-hematite phases which are chemically unstable. If the magnetic grains of Type II and Type III 
Magnetic Properties of Submarin Basalts
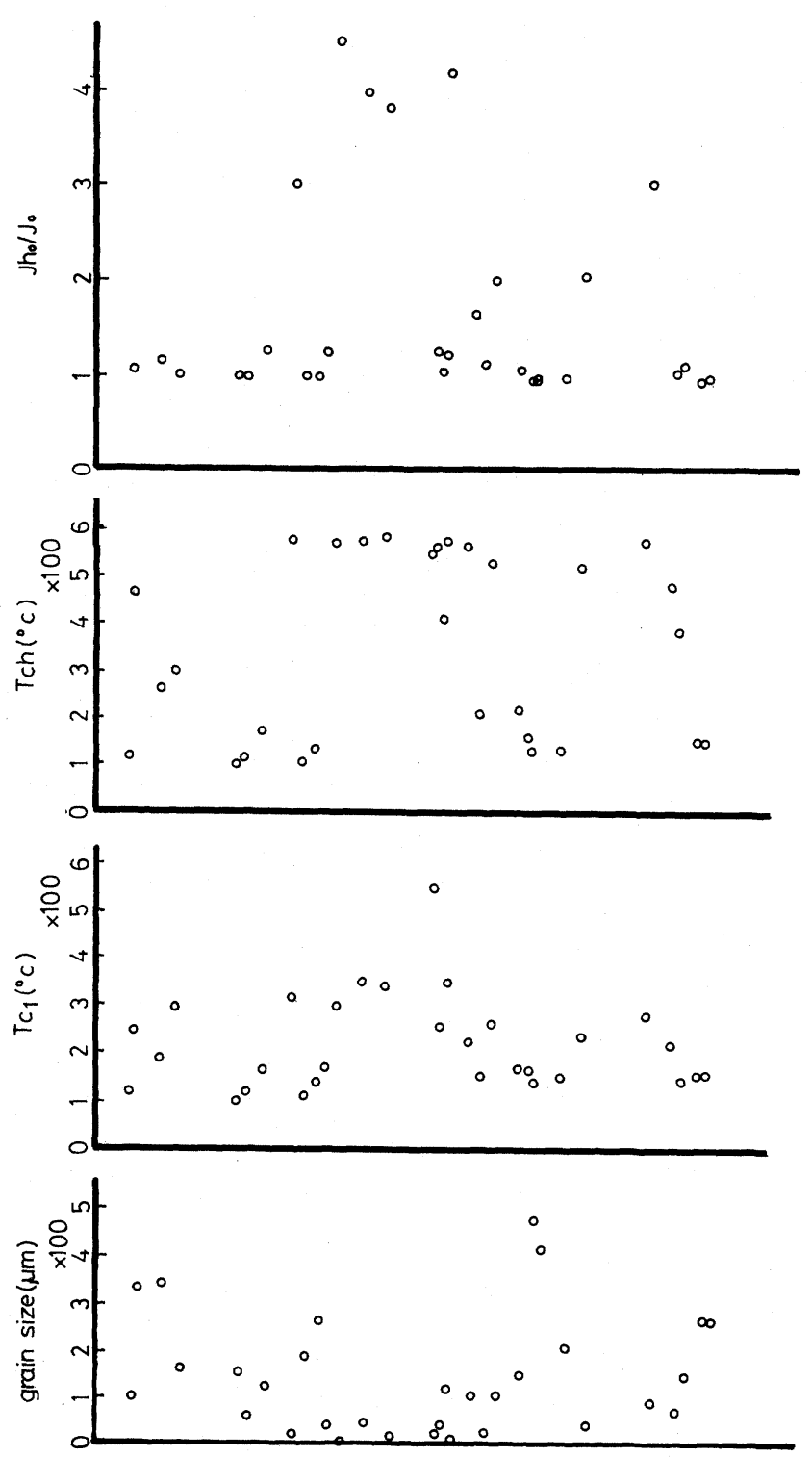

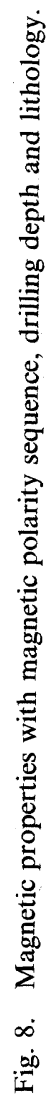

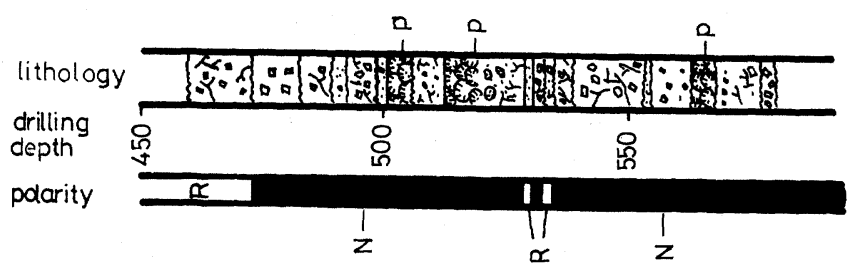



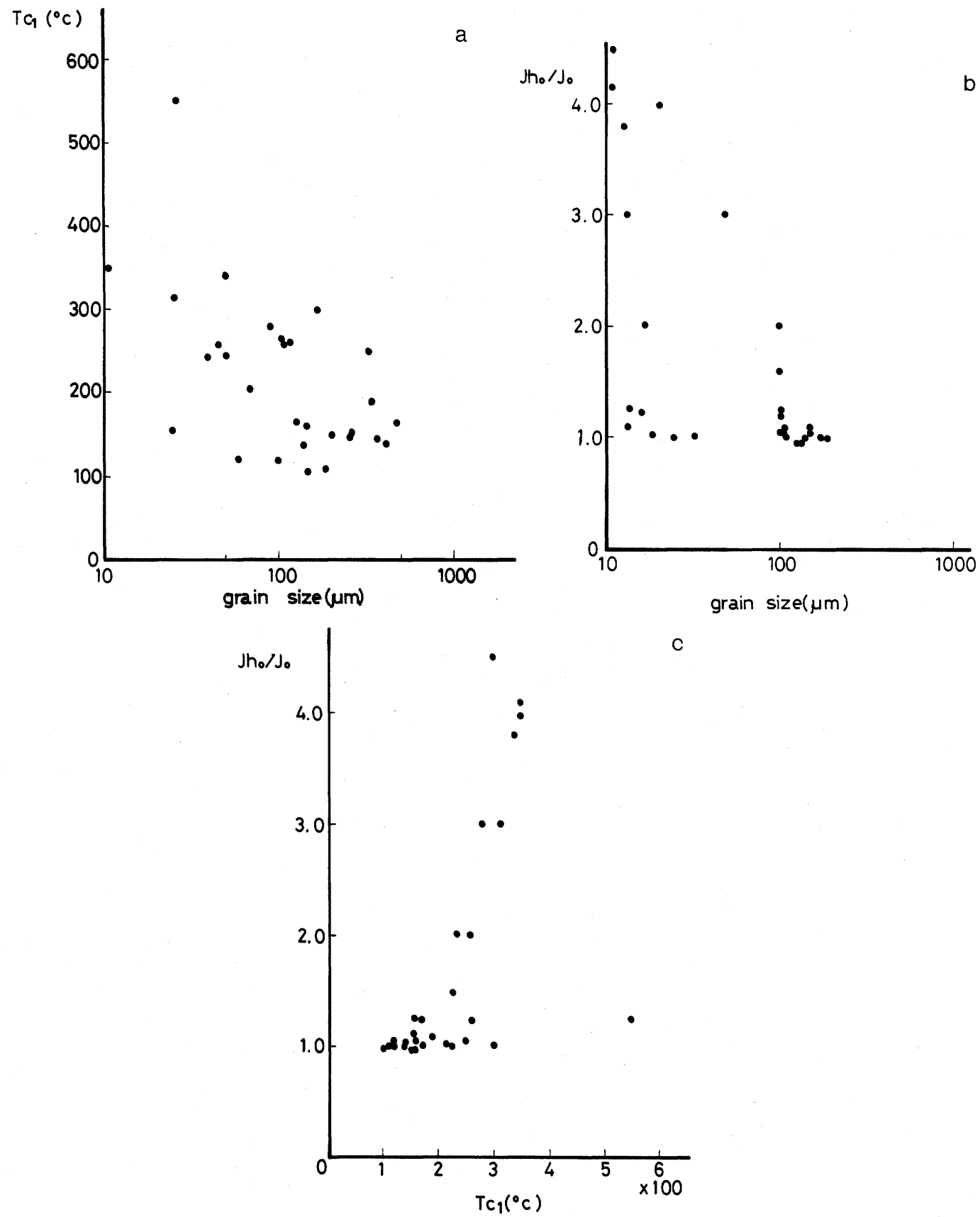

Fig. 9. (a) $T c_{1}$ versus grain size. (b) $J h_{0} / J_{0}$ ratio versus grain size. (c) $J h_{0} / J_{0}$ ratio versus $T c_{1} J h_{0} / J_{0}$ : The intensity ratio of saturation magnetizations at room temperature before and after heating at $620^{\circ} \mathrm{C}$. 
include titanomaghemite which is due to low temperature oxidation and the magnetic grains of Type IV include the "immature" ilmenite, both the magnetic grains of Type II and III and Type IV are thought of as non-stoichiometric titanomagnetites which have excess oxygen.

The $J s-T$ curves of the heated specimen of Type IV (Fig. 4) are irreversible and it is thought that the two phases, into which the virgin titanomagnetites unmixed in thermomagnetic measurements, were re-mixed and were synthesized into nonstoichiometric titanomagnetites. This seems to be true because it has a lower $T c_{1}$ than $T c_{h}, T c_{h}$ being almost the same temperature in every specimen, as will be mentioned later. The Curie temperature $\left(T c_{1}\right)$ of the synthesized products are different from each other as seen in Fig. 4. This fact makes us suppose that the synthesized product may depend on two conditions, the heating temperature and the length of heating. Although the conditions of heating are different in each case, in the $J_{s-} T$ curves which indicate irreversible changes, the $T c_{h}$ of the heated specimen is nearly equal to the $T c_{h}$ of the virgin specimen. Thus, apparently, the spinels synthesized by heat treatment are also unstable in the heating process of thermomagnetic measurements, and they unmix into a ilmenite-hematite phase and a less titaniferous magnetite. The curves of heated specimens of Type III (Fig. 3) are also explained by the same chemical procedure as above-mentioned (Type IV).

If we regard the irreversible change in the $J s-T$ curves of the heated specimen as oxidation-reduction reaction, it should be considered that oxidation occurs on the thermomagnetic measurement and that reduction occurs on the heat treatment. Since both experiments were carried out in vaccum of $10^{-3}$ torr, which is generally regarded as atmosphere of oxidation below $1,000^{\circ} \mathrm{C}$, it is reasonable to understand that the reduction on the heat treatment was induced by buffers such as sulfides and silica, which could not be separated completely from the magnetic minerals as the specimen.

There are, however, a few doubtful points mentioned as follows:

1) Whether or not the buffers such as sulfides and silica are stable to the repetition of reduction in the heat treatment?

2) Why is the magnetic produced by unmixing so stable to the repetition of the oxidation in the thermomagnetic measurements?

It is therefore, also supposed that the so-called mixing and unmixing mentioned above may constitute a closed system in terms of the chemical changes and that oxidation-reduction reaction may occur inside the magnetic grains (partly oxidized and partly reduced). However, the mechanism of irreversible changes as seen in the $J_{S}-T$ curves in this study is not made clear. Clearing up uncertainties with regard to the mechanism, it is desirable that the quantitative analyses of oxygen in the magnetic minerals is done.

Summaries of the nature of the four types classified by $J s-T$ curves are as follows:

1) The samples of Type I contain titanomagnetites which are chemically stable in heat. The magnetic grains retain the original condition at the time when submarine basalts were generated.

2) The samples of Type II and Type III contain titanomaghemites which are 

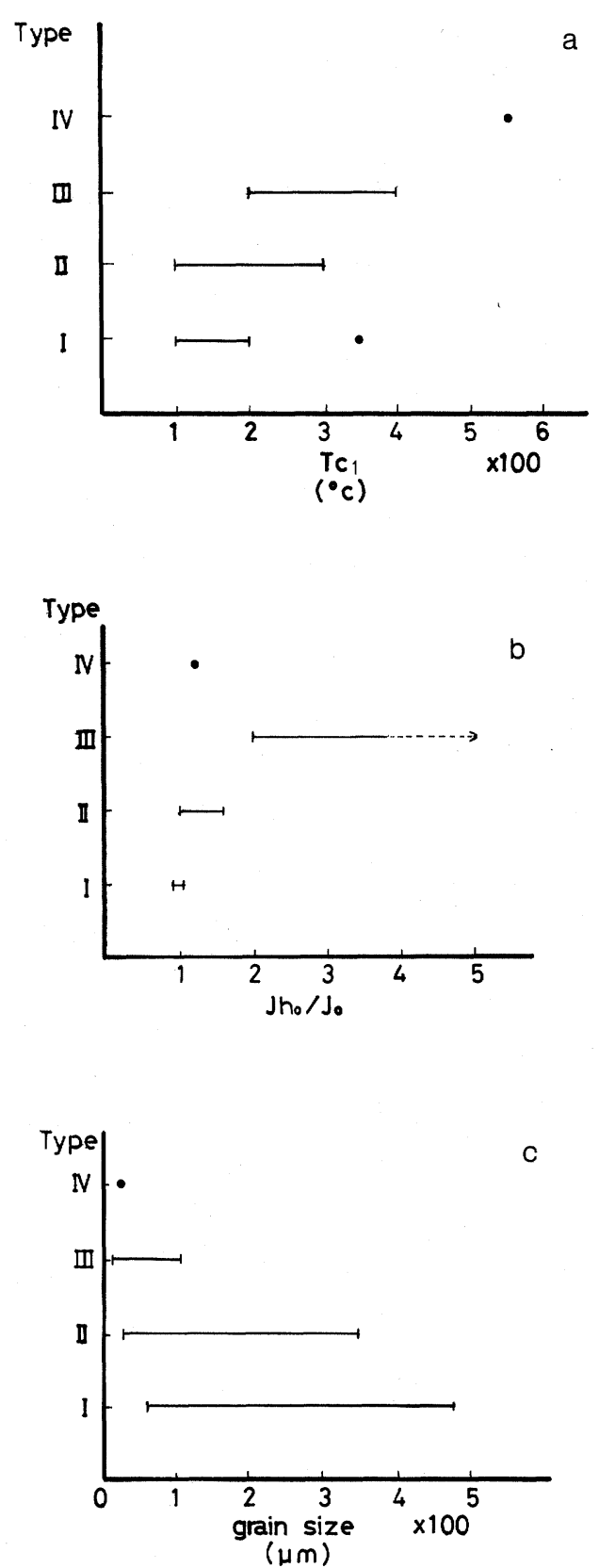

Fig. 10. The distributions of $T c, J h_{0} / J_{0}$ ratio and grain size of four types. ( $J h_{0} / J_{0}=$ the intensity ratio of saturation magnetizations at room temperature before and after heating at $620^{\circ} \mathrm{C}$ ). 


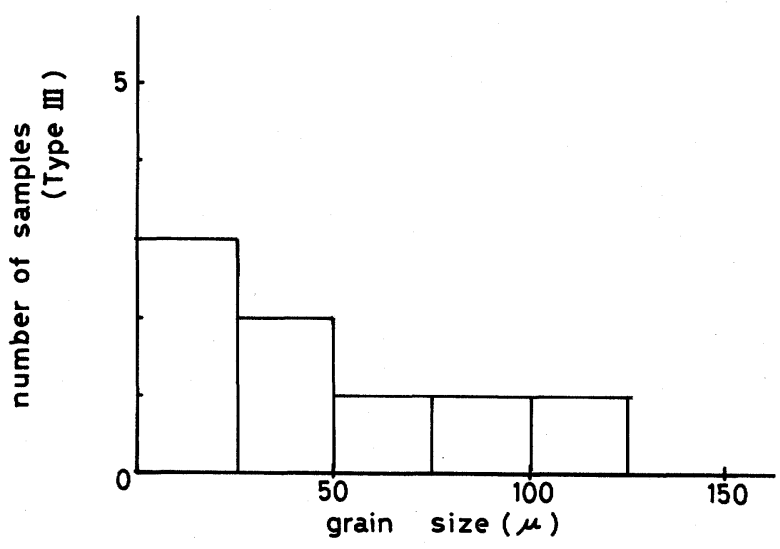

Fig. 11. The histogram of grain size distribution in Type III.

oxidized titanomagnetites and chemically meta-stable to heat. It has a tendency that the grain sizes of the magnetic grains of Type II and Type III are smaller than those of Type I, as seen in Fig. 10. The magnetic grains suffered low temperature oxidation after they had been generated. The grade of low temperature oxidation of Type III is higher than that of Type II.

3) The sample of Type IV is only one of 31 samples and it is observed that the grain sizes of the magnetic grains of this sample are very small. The $J_{S}-T$ curve of the virgin specimen of this type resembles one of the $J_{S}-T$ curves of the heated specimens of Type III (Fig. 3-b), and it is supposed that the magnetic grains of Type IV consist of two phases, ilmenite-hematite phase and less-titaniferous magnetite phase. The magnetic grains, which already suffered low temperature oxidation on the sea floor, were heated by some heat source.

If the chemical composition of the titanomagnetites in submarine basalts is almost the same ( $X=0.6,0.7$ ), it seems possible that relatively high $T c_{1}$ is due to low temperature oxidation. $J h_{0} / J_{0}$ of the magnetic grains is proportional to its $T c_{1}$, as seen in Fig. 9-c. Therefore, $J h_{0} / J_{0}, T c$ can be used as factors to estimate low temperature oxidation. From the dependence of $T c_{1}$ and $J h_{0} / J_{0}$ on grain sizes in Figs. 9-a and b, it is considered that small grains of magnetic minerals suffer low temperature oxidation more easily than larger grains. This consideration seems to be supported by Fig. 11 for the number of Type III samples grouped in the range of small grain sizes.

Most of the $\mathrm{Fe}-\mathrm{Ti}$ oxide minerals in natural samples seem to contain trace components such as $\mathrm{Al}_{2} \mathrm{O}_{3}$, judging from the results of the microprobe analyses. Nevertheless all the considerations in this paper have been done without regard to any trace components, for the sake of convenience. It is significant, however, to consider the influences of the trace components for the studies of rock magnetism in order to establish more complete concepts on magnetic properties. 


\section{Conclusion}

Most of the results in this study seem to support the results of FURUTA et al. (1980).

1) The $X$-values of titanomagnetites in this study concentrate between 0.6 to 0.7 and resemble the $X$-values of submarine basalts.

2) Four types of $J_{s}-T$ curves of virgin samples are found in this study, and each type shows a different character.

3) The magnetic properties and mineralogical properties of the samples are correlative to the grain size of the titanomagnetites and lithological facies of the rocks.

From the above we can conclude the following: Non-stoichiometric titanomagnetites such as titanomaghemites are unmixed by heat, however, unmixed phases are not mixed back perfectly into the chemically stable (stoichiometric) titanomagnetites, so as to indicate a reversible change in the $J s-T$ curve, by the heat treatment in this study.

I would like to express my sincere appreciation to Professor K. Momose for helpful discussion and suggestion. I am indebted to Professor K. Kobayashi and Mr. Furuta for giving me the opportunity of this study and their helpful suggestions. I am very greateful to professor $\mathrm{K}$. Yaskawa for critical reading of the manuscript and valuable suggestions on it. And I am very great ful to Dr. M. B. Stainer for careful reading of the typescript and cordial comments on it.

\section{REFERENCES}

Day, R., S. Halgedahl, M. Stainer, K. Kobayashi, T. Furuta, T. Ishit, and A. Fuller, Magnetic properties of basalts from DSDP Leg 49, Init. Repts. DSDP, 49, 781-792, Washington (U.S. Govt. Printing Office), 1979.

Dick, H. J. B., N. G. Marsh, and T. D. Bullen, Deep Sea Drilling Project Leg 58 abyssal basalts from the Shikoku basin: Their petrology and major-element geochemistry, Init. Repts. DSDP, 58, 843-872, Washington (U.S. Govt. Printing Office), 1980.

Furuta, T., Magnetic properties of basalt samples of Holw 504B and 505b on the Costa Rica rift, Deep Sea Drilling Project Leg 69 and Leg 70, Init. Repts. DSDP, 69, Washington (U.S. Govt. Printing Office) (in press).

Furuta, T., K. Kobayashi, and K. Momose, Magnetic properties of ignious rocks of the Philiphine Sea, Deep Sea Drilling Project, Init. Repts. DSDP, 58, 923-934, Washington (U.S. Govt. Printing Office), 1980.

Gromme, C. S., T. L. Wright, and D. L. PeCK, Magnetic properties and oxidation of iron-titanium oxide minerals in Alae and Makaopuhi lava lakes, Hawaii, J. Geophys. Res., 74, 5277-5293, 1969.

Gromme, S., E. A. Mankinen, M. Marshall, and R. S. Coe, Geomagnetic paleointensities by the Thelliers' method from submarine pillow basalts : Effects of seafloor weathering, J. Geophys. Res., 84, 3553-3575, 1979.

HALl, J. M., L. K. FINK, and H. P. Johnson, Petrography of opaque minerals, Leg 34, Init. Repts. DSDP, 34, 349-362, Washington (U.S. Govt. Printing Office), 1976.

Hamano, Y., T. Nishitani, and M. Kono, Magnetic properties of basalt samples from Deep Sea Drilling Project Hole 417D and 418A, Init. Repts. DSDP, 51, 52, 53, 1391-1405, Washington (U.S. Govt. Printing Office), 1979. 
Johnson, H.P. and J. M. HALL, A detail rock magnetic and Opaque mineralogical study of the basalt from the Nazca Plate, Geophys. J. R. Astr. Soc., 152, 45-64, 1978.

Klein, G. deV., K. Kobayashi, S. M. White, H. Chamley, D. Curtis, A. Mizuno, H. Dick, G. V. Nisterenko, N. G. Marsh, D. Waples, D. J. Echols, H. Okada, J. R. Sloan, D. M. Fountain, and H. Kinoshita, Site 443, Shikoku basin, Deep Sea Drilling Project Leg 58, Init. Repts. DSDP, 58, 109-218, Washington (U.S. Govt. Printing Office), 1980.

Kobayashi, K., M. Stainer, A. Fuller, T. Furuta, T. Ishit, P. Shive, and R. Day, Magnetic mineralogy of basalts from Leg 49, Init. Repts. DSDP, 49, 793-805, Washington (U.S. Govt. Printing Office), 1979.

MARSHALL, M., The magnetic properties of some DSDP basalts from the North Pacific and inferences for Pacific plate tectonics, J. Geophys. Res., 83, 289-308, 1978.

Marshall, M. and A. Cox, Magnetic changes in basalt due to sea floor weathering, J. Geophys. Res., 77, 6459-6469, 1972.

Mryashiro, A., Kaiyo-chishitsu, edited by N. Nasu, Kaiyogaku-Koza, 5, 183-194, Univ. of Tokyo Press, 1976 (in Japanese).

NAKAmura, Y. and I. Kushiro, Compositional relations of coexisting orthopyroxene, pigeonite and augite in a tholeiitic andesite from Hakone volcano, Contr. Mineral. Petrol., 26, 265-275, 1970.

NishitANI, T., Low temperature oxidation of titanomagnetite and its effect on the remanent magnetization in basaltic rocks, Doctor Thesis (M. S.), Univ. Tokyo, 129 pp., 1979.

O'ReILly, W., Estimation of the Curie temperature of maghemite and oxidized titanomagnetites, $J$. Geomag. Geoelectr., 20, 381-386, 1968.

Ozima, M. and E. E. LARSON, Study on irreversible change of magnetic properties of some ferromagnetic minerals, J. Geomag. Geoelectr., 19, 117-127, 1967.

Ozima, M. and E. E. LARSON, Low- and high-temperature oxidation of titanomagnetite in relation to irreversible change in the magnetic properties of submarine basalts, J. Geophys. Res., 75, 1003-1017, 1970.

Ozima, M. and M. Ożıma, Characteristic thermomagnetic curve in submarine basalts, J. Geophys. Res., 76, 2051-2056, 1971.

Ozima, M. and N. Sакамото, Magnetic properties of synthesized titanomagnetite, J. Geophys. Res., 76, 7035-7046, 1971.

Ozima, M., M. Ozima, and I. Kaneoka, Potassium-argon ages and magnetic properties of some dredged submarine basalts and their geophysical implications, J. Geophys. Res., 73, 711-723, 1968.

STAINER, M. B., Magnetic and mineralogical investigations of opaque minerals : preliminary results, Init. Repts. DSDP, 61, 731-742, Washington (U.S. Govt. Printing Office), 1981.

STAINER, M. B., An investigation of ulvospinel composition and cation migration during magnetization in Deep Sea Drilling Project Leg 61 titanomagnetites, J. Geophys. Res., 87, 5361-5374, 1982. 